\title{
Hemostasis Techniques for Non-variceal Upper GI Hemorrhage: Beyond Injection and Cautery
}

\author{
B. Nulsen ${ }^{1,2,3,5} \cdot$ D. M. Jensen ${ }^{1,2,3,4}$
}

Accepted: 5 April 2021 / Published online: 8 June 2021

(c) The Author(s) 2021

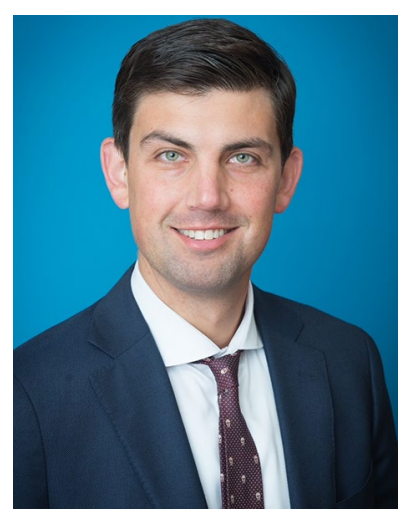

B. Nulsen

Keywords Non-variceal upper GI hemorrhage $\cdot$ Doppler endoscopic probe $\cdot$ Over-the-scope clip $\cdot$ Hemostatic powder

$\begin{array}{ll}\text { Abbreviations } \\ \text { APC } & \text { Argon plasma coagulation } \\ \text { DEP } & \text { Doppler endoscopic probe } \\ \text { DL } & \text { Dieulafoy's lesion } \\ \text { FDA } & \text { United States Food and Drug Administration } \\ \text { GAVE } & \text { Gastric antral vascular ectasia } \\ \text { HC } & \text { Hemoclip } \\ \text { MPEC } & \text { Multipolar electrocautery } \\ \text { MWT } & \text { Mallory-Weiss Tear } \\ \text { NBVV } & \text { Non-bleeding visible vessel } \\ \text { NNT } & \text { Number needed to treat } \\ \text { NVUGIH } & \text { Non-variceal upper GI hemorrhage } \\ \text { OTSC } & \text { Over-the-scope clip } \\ \text { PUBs } & \text { Peptic ulcer bleeds } \\ \text { RCT } & \text { Randomized clinical trial } \\ \text { SRH } & \text { Stigmata of recent hemorrhage }\end{array}$

B. Nulsen

bnulsen@mednet.ucla.edu

Extended author information available on the last page of the article

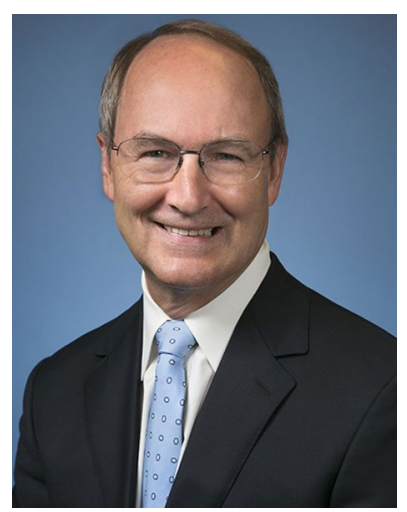

D. M. Jensen

\section{Introduction}

Acute non-variceal upper GI hemorrhage (NVUGIH) is a common indication for hospitalization in the USA with a reported incidence of 66.7 cases per 100,000 [1]. Peptic ulcer disease, gastroduodenal erosions, Mallory-Weiss tears (MWT) and esophagitis are frequent causes of NVUGIH and account for more than $80 \%$ of cases. Other less common etiologies include Cameron ulcers, UGI cancers, angiodysplasia, polyps, gastric antral vascular ectasia (GAVE), and Dieulafoy's lesions (DL).

Recurrent NVUGIH is common in high-risk patients and is associated with complications and increased mortality [2-9]. The current standard of care is to treat patients with severe NVUGIH with endoscopic therapy based on visual stigmata of recent hemorrhage [SRH] [2-4]. These standard treatments include thermocoagulation (argon plasma coagulation $[\mathrm{APC}]$, multipolar electrocautery [MPEC]) and through-the-scope hemoclips [HC], either alone or in combination with epinephrine pre-injection [3, 9]. For NVUGIH, the goals of endoscopic treatment are to control active bleeding and prevent rebleeding by obliterating arterial blood flow underneath the SRH $[10,11]$. However, rebleeding still occurs in up to $26 \%$ of high-risk patients with major SRH in peptic ulcers despite these therapies based on visual 
criteria [10]. Several promising techniques have emerged in the last decade which are important options for reducing rebleeding rates and improving clinical outcomes (Table 1). This review will present the scientific evidence for these novel strategies, including whether they result in definitive hemostasis, which is defined as successful endoscopic treatment of high-risk patients for control of active bleeding and prevention of rebleeding.

\section{Doppler Endoscopic Probe}

The Doppler endoscopic probe was first described in 1982 [12]. As a single-use endoscopic probe and device (DEP; Vascular Technology Inc, Nashua, NH), this is approved by the United States Food and Drug Administration (FDA). It does not provide direct hemostasis, but assists in lesion risk stratification by identifying underlying arterial blood flow, mapping its path, and guiding endoscopic hemostasis $[10,11]$. This is especially useful in lesions with SRH and underlying arteries such as oozing bleeding, non-bleeding visible vessels and flat spots, whose characterization can be challenging and subjective compared to visual cues alone $[11,13]$. In addition to risk stratification, DEP can also be used to confirm eradication of arterial blood flow after endoscopic therapy for definitive hemostasis in lesions with SRH $[10,11]$.

DEP is easy to use and to teach endoscopists how to apply $[10,11,14]$. The tip of the Doppler probe is lubricated and passed through the working channel of the diagnostic or therapeutic upper endoscope. It is then lightly applied to the SRH in a tangential orientation and then moved away from the SRH for 5-10 $\mathrm{mm}$ in a straight line [10,11]. This is then repeated in four different quadrants to detect the direction of blood flow and location of the underlying vessel (Fig. 1) [10, 11]. While the use of Doppler has primarily been described in treating peptic ulcers, it can also be used for other focal non-variceal upper GI lesions with underlying arteries such as Dieulafoy's lesions and Mallory-Weiss tears [10, 11, 15].

Advantages of the DEP system are its ability to guide risk stratification and validate risk of visual SRH, its low cost (\$150-\$200 USD), ease of use, and safety. Disadvantages include endoscopists needing to learn a new technique, possible variability among endoscopists in DEP signal interpretation, and nominal extra cost of disposable probes (Table 2).

Several cohort studies reported DEP as a promising tool for stratifying patients with focal lesions and SRH at high risk of rebleeding and improving rebleeding rates (Table 3). The outcomes reported in earlier studies are limited in current relevance by use of injection monotherapy (now regarded as less effective) and second look endoscopy (not routinely used and not recommended) [16-19]. However, a 2016 prospective cohort study examined the use of DEP in patients with severe peptic ulcer bleeding and reported that $27.4 \%$ of patients with major SRH (arterial spurting-Forrest $1 \mathrm{~A}$, non-bleeding visible vessel [NBVV]-Forrest 2A, and adherent clot-Forrest 2B) had residual arterial blood flow after modern, standard of care visually guided endoscopic treatment (MPEC or HC) [11]. The investigators additionally identified arterial blood flow underlying pigmented spots (Forrest 2C) in $40.5 \%$ of ulcer patients, which typically are not treated according to current guidelines [3, 9]. They later reported that rebleeding occurred in $20 \%$ of chronic ulcers with flat spots in patients treated medically [10]. The authors also concluded that DEP was more accurate than SRH alone to risk stratify ulcers for rebleeding at baseline and was useful as a guide for definitive endoscopic hemostasis of bleeding ulcers (Table 2, 3, 4, 5, 6).

A recent randomized clinical trial (RCT) supported the use of DEP in NVUGIH to improve clinical outcomes. This study compared standard visually guided therapy to DEPguided treatment in 148 patients with severe NVUGIH (84.5\% peptic ulcers, $12.8 \%$ DL and $2.7 \%$ bleeding MWT) [10]. The investigators reported a significantly lower rate of 30-day rebleeding among patients in the Doppler group ( $26.3 \%$ vs. $11.1 \% ; \mathrm{p}=0.021)$ with a number needed to treat [NNT] of 7. By Kaplan-Meier analysis, there was a significant difference in time to lesion rebleeding $(\mathrm{p}=0.017)$. There were also arithmetic lower rates of surgery, death, major complications, transfusions, and hospital days in the DEP group. This RCT also importantly identified that $89 \%$ of patients with residual post-treatment arterial blood flow ultimately rebled, as compared to $0 \%$ among patients with a positive post-treatment DEP that was further treated until negative $(89.9 \%$ vs. $0.0 \%$; $<0.001)$. This finding corroborated earlier cohort studies which reported increased risk of rebleeding in patients with persistently positive posttreatment arterial blood flow in peptic ulcers $[19,20]$. This study was included in a recent meta-analysis which found significantly lower rates of rebleeding [OR 0.13 (95\% CI 0.04-0.44); $\mathrm{P}=0.001$ ], need for surgery [OR 0.05 (95\% CI 0.01-0.24); $\mathrm{P}<0.001]$, and bleeding associated mortality [OR 0.19 (95\% CI 0.05-0.81); I =0.00; $\mathrm{P}=0.025$ ] among 284 patients randomized to treatment with DEP versus conventional management [21].

As a corollary, persistent arterial blood flow under SRH usually causes rebleeding in high-risk patients with focal NVUGIH [10, 11]. These results emphasize that arterial blood flow underneath the SRH in focal lesions (such as ulcers and DL) is a major risk factor for lesion rebleeding. Obliteration of arterial blood flow underneath SRH prevents rebleeding $[10,11]$.

In addition to its promising effect on clinical outcomes, DEP has an excellent safety profile. In a meta-analysis of 526 patients enrolled in ten studies, no patients experienced any DEP-related adverse events [21]. DEP has also been 
Table 1 Summary table of DEP assisted treatment, OTSC, and TC-325 for NVUGIH

\begin{tabular}{llll}
\hline Treatment & DEP assisted & OTSC & TC-325 \\
\hline Type of action & $\begin{array}{c}\text { Monitoring of thermal or mechani- } \\
\text { cal hemostasis }\end{array}$ & $\begin{array}{c}\text { Mechanical (large clip) } \\
\text { hemostasis }\end{array}$ & Topical Spray \\
$\begin{array}{l}\text { Indication by stigmata of recent } \\
\text { hemorrhage (SRH) }\end{array}$ & & & \\
$\begin{array}{l}\text { Major SRH } \\
\text { Arterial bleeding (Forrest 1A) }\end{array}$ & Yes & Yes & Yes \\
NBVV (Forrest 2A) & Yes & Yes & No \\
Adherent Clot (Forrest 2B) & Yes & Yes & No \\
Lesser SRH & & & Yes \\
Oozing (Forrest 1B) & Yes & Yes & No \\
Flat spot (Forrest 2C) DEP+ & Yes & Yes & No \\
Obliterate underlying arterial flow & Yes & Yes & $20-25 \%$ \\
Rebleed rate for peptic ulcer bleeds & Arterial flow obliterated: 0\% & $5-10 \%$ & Diffuse or tumor bleeding \\
& Arterial flow not obliterated: 11\% & & Rescue treatment \\
Main indications & Focal NVUGI lesions with SRH & Focal NVUGI lesions with & \$2500 \\
\hline
\end{tabular}

shown to be cost effective when compared to conventional, visually guided therapy in acute peptic ulcer bleeding (PUB) in several different cost-analyses [22-24]. As one example, when used to direct treatment of ulcers with flat pigmented spots (Forrest 2C), DEP-guided therapy was more effective and less expensive than visually guided hemoclips over a 30 day time horizon [23].

\section{OTSC}

The large, over-the-scope clip (OTSC; Ovesco Endoscopy, Tuebingen, Germany) is a novel endoscopic clipping device that was first reported in 2007 in a case series which described its successful use in repair of gastrointestinal perforations and treatment of GI bleeding [25]. The OTSC applicator cap attaches to the tip of the endoscope similar

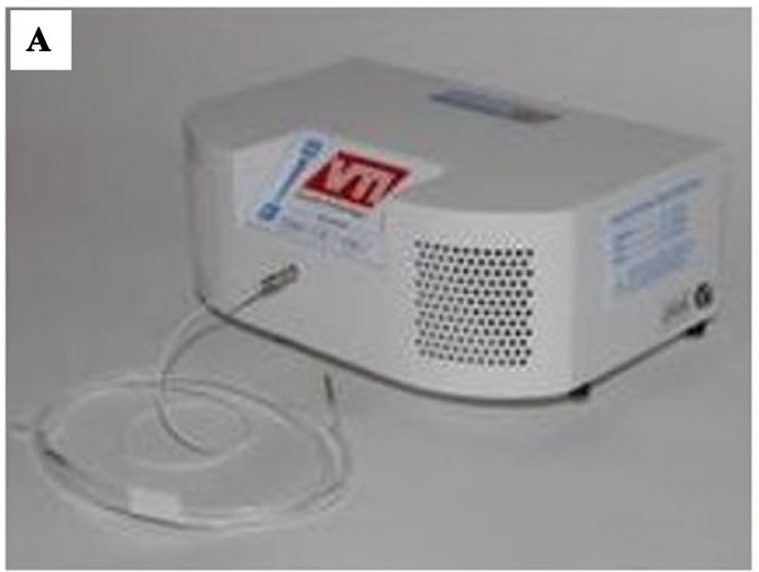

to a band ligation device. There are multiple sizes ranging from 11 to $14 \mathrm{~mm}$ (depending on the size of endoscope that is being used) and also types of teeth (blunt and several sharp versions for various applications) (Fig. 2). OTSC was later described as a treatment for NVUGIH in retrospective and cohort studies and meta-analyses, with high rates of technical success and rebleeding rates ranging from 0 to $35 \%$ [26-34]. In addition to their retrospective design, these studies are limited by heterogeneity in terms of bleeding etiology, location, and therapeutic timing.

Advantages of OTSC include its ability to embed in and treat large or fibrotic ulcers due to its size and significant compression force; relatively infrequent complications; and modest cost (\$400-\$450 USD) (Fig. 3). Disadvantages include the need to remove the endoscope, attach the applicator cap (often to a smaller endoscope), and reintubate the patient prior to treatment; difficulty passing through luminal

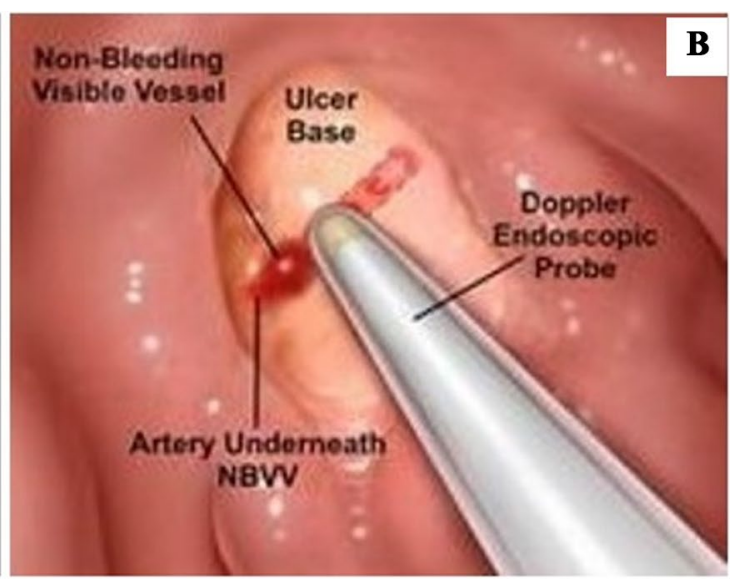

Fig. 1 Doppler endoscopic probe transceiver and use to map arterial anatomy underlying Forrest 2A ulcer 
Table 2 Advantages and disadvantages of novel techniques for management of NVUGIH

\begin{tabular}{lll}
\hline Hemostasis modality & Advantages & Disadvantages \\
\hline Doppler endoscopic probe (DEP) & $\begin{array}{l}\text { Easy to learn and apply } \\
\text { Does not require withdrawal of endoscope } \\
\text { prior to use } \\
\text { No complications }\end{array}$ & $\begin{array}{l}\text { Auditory interpretation of Doppler signal } \\
\text { Does not provide direct hemostasis }\end{array}$ \\
& Inexpensive & \\
& Ability to grasp a large volume of tissue & Requires endoscope withdrawal to load device \\
& Ability to grasp and embed in fibrotic & Challenging to intubate esophagus or traverse luminal \\
tissue & stenosis \\
& Infrequent complications & Difficult to position and deploy onto tangential positions \\
& Does not require focal/targeted treatment & Technical complications (occlusion of spray catheter or \\
& Non-thermal and non-traumatic & instrument channel) \\
& Ability to treat diffuse lesions (e.g., & Sloughs off quickly (<24 h) \\
tumors) & Does not obliterate underlying arterial or venous blood \\
& Relative ease of deployment & flow \\
& & Reduced lesion visualization after use \\
& & Expensive
\end{tabular}

Table 3 Prospective studies of the Doppler endoscopic probe (DEP) in Non-variceal Upper GI Hemorrhage (NVUGIH)

\begin{tabular}{|c|c|c|c|c|c|}
\hline Author & Study design and size $(\mathrm{N})$ & Study population & Treatment & Rebleeding rates & Important secondary Outcomes \\
\hline Jaspersen [52] & $\begin{array}{l}\text { Prospective } \\
\mathrm{N}=11\end{array}$ & $\begin{array}{l}\text { Ulcers } \\
\text { (Forrest II) }\end{array}$ & Injection $^{\wedge}$ & $\mathrm{DEP}+: 9 \%(1 / 11)$ & $\begin{array}{l}\text { Second look endoscopy: } \\
0 \% \text { residual DEP }+\end{array}$ \\
\hline Kohler [16] & $\begin{array}{l}\text { Cohort } \\
\mathrm{N}=140\end{array}$ & $\begin{array}{l}\text { Ulcers } \\
\text { (Forrest II-III) }\end{array}$ & Injection $^{\wedge}$ & $\begin{array}{l}\text { DEP + : } 9 \%(7 / 78) \\
\text { DEP -: } 0 \%(0 / 72)\end{array}$ & $\begin{array}{l}\text { Second look endoscopy: } \\
21 \% \text { residual DEP + }\end{array}$ \\
\hline Kohler [18] & $\begin{array}{l}\mathrm{RCT} \\
\mathrm{N}=100\end{array}$ & $\begin{array}{l}\text { Ulcers } \\
\text { (Forrest II-III) }\end{array}$ & Injection^^ & $\begin{array}{l}\text { SRH: } 14 \% \\
\text { DEP: } 2 \% *\end{array}$ & $\begin{array}{l}\text { Surgery: } \\
\text { SRH 5\% vs. DEP 0\%* }\end{array}$ \\
\hline Wong [20] & $\begin{array}{l}\text { Observational } \\
\mathrm{N}=55\end{array}$ & $\begin{array}{l}\text { PUD } \\
\text { (Forrest I-III) }\end{array}$ & $\begin{array}{l}\text { Injection }^{\wedge} \\
\pm \text { Thermal }\end{array}$ & $\begin{array}{l}\text { Post-treatment DEP(-): } \\
\text { Pre DEP +: } 11 \%(1 / 9) \\
\text { Pre DEP -: } 0 \%(0 / 11)\end{array}$ & $\begin{array}{l}\text { Post-treatment DEP: } \\
\text { Positive: } 100 \% \\
\text { Negative: } 11 \% *\end{array}$ \\
\hline $\begin{array}{l}\text { Van Leerdam } \\
\text { [19] }\end{array}$ & $\begin{array}{l}\text { Cohort } \\
\mathrm{N}=50 \\
\text { Randomized } \\
\mathrm{N}=30\end{array}$ & $\begin{array}{l}\text { Ulcers } \\
\text { (Forrest Ib-IIb) } \\
\text { Ulcers } \\
\text { (Forrest IIc-III) }\end{array}$ & Injection $^{\wedge}$ & $\begin{array}{l}\mathrm{DEP}+: 12 \%(5 / 41) \\
\mathrm{DEP}-: 22 \%(2 / 9) \\
\mathrm{DEP}+: 0 \% \\
\mathrm{DEP}-: 7.1 \%\end{array}$ & $\begin{array}{l}\text { Post-treatment DEP: } \\
\text { Positive: } 27 \%(3 / 11) \text { rebleed } \\
\text { Negative: } 4 \%(1 / 27) \text { rebleed } *\end{array}$ \\
\hline Jakobs [53] & $\begin{array}{l}\text { Prospective } \\
\mathrm{N}=9\end{array}$ & Ulcers & Injection $^{\wedge}$ & $20 \%(4 / 20)$ & $\begin{array}{l}\text { Second look endoscopy: } \\
\text { Surgery: } \\
\text { Post-treatment DEP Neg } 10 \% \\
\quad(2 / 20)\end{array}$ \\
\hline Jensen [11] & $\begin{array}{l}\text { Observational } \\
\mathrm{N}=162\end{array}$ & $\begin{array}{l}\text { Ulcers } \\
\text { (Forrest I-III) }\end{array}$ & $\begin{array}{l}\text { MPEC/ } \\
\text { Hemoclip } \\
\pm \text { Injection^ }^{\wedge}\end{array}$ & $\begin{array}{l}\text { Forrest 1A: } 29 \% \\
\text { Forrest 1B: } 0 \%^{*}\end{array}$ & $\begin{array}{l}\text { Post-treatment Residual DEP+ } \\
\text { Forrest 1A, 2A, 2B: } 27.4 \% \\
\text { Forrest 1B: } 0 *\end{array}$ \\
\hline Jensen $[10]$ & $\begin{array}{l}\mathrm{RCT} \\
\mathrm{N}=148\end{array}$ & $\begin{array}{l}\text { Ulcers } \\
\text { (Forrest I-IIc) } \\
\text { Dieulafoy's } \\
\text { MWT }\end{array}$ & $\begin{array}{l}\text { MPEC/ } \\
\text { Hemoclip } \\
\pm \text { Injection^ }^{\wedge}\end{array}$ & $\begin{array}{l}\text { DEP: } 11.1 \%(8 / 72) \\
\text { Standard: } 26.3(20 / 76)^{*}\end{array}$ & $\begin{array}{l}\text { Post-treatment DEP: } \\
\text { Positive: } 88.9 \% \text { rebleed } \\
\text { Negative: } 0 \% \text { rebleed }^{*}\end{array}$ \\
\hline
\end{tabular}

*Indicates significant $\mathrm{p}$ value $(<0.05)$

${ }^{\wedge}$ Injection of dilute epinephrine (1:10,000 or 1:20,000) and/or sclerosant 
Table 4 Prospective studies of the over-the-scope clip (OTSC) in Non-variceal Upper GI Hemorrhage (NVUGIH)

\begin{tabular}{|c|c|c|c|c|c|}
\hline Author & $\begin{array}{l}\text { Study design and } \\
\text { size }(\mathrm{N})\end{array}$ & Study population & Treatments & Rebleeding rates & Significant secondary outcomes \\
\hline Schmidt [37] & $\begin{array}{l}\text { RCT } \\
(\mathrm{N}=66) \\
\text { Not blinded } \\
19 \text { center }\end{array}$ & $\begin{array}{l}\text { Recurrent Ulcer } \\
\text { Bleeding }\end{array}$ & $\begin{array}{l}\text { OTSC-33 } \\
\text { Standard-33 } \\
\text { (cross-over) }\end{array}$ & $\begin{array}{l}\text { "Further bleeding" } \\
\text { @ } 7 \text { days } \\
\text { OTSC-15.2 } \\
\text { Standard-57.6 }\end{array}$ & $\begin{array}{l}\text { Cumulative } 30 \text {-day "further } \\
\text { bleeding" in OTSC (including } \\
14 \text { crossover): } 10.6 \%\end{array}$ \\
\hline Jensen [36] & $\begin{array}{l}\text { RCT } \\
(\mathrm{N}=53) \\
\text { Blinded } \\
2 \text { centers }\end{array}$ & $\begin{array}{l}\text { Initial treatment of } \\
\text { Ulcers \& Dieula- } \\
\text { foy's Lesions with } \\
\text { major or lesser } \\
\text { SRH }\end{array}$ & $\begin{array}{l}\text { OTSC-25 } \\
\text { Standard-28 } \\
\text { (no cross-over) }\end{array}$ & $\begin{array}{l}\text { 30-day rebleeding: } \\
\text { OTSC: } 28.6 \% \\
\text { Standard: } 4 \%\end{array}$ & $\begin{array}{l}\text { Medical complications: } \\
\text { OTSC }(0 \%) \text { vs. Standard } \\
(14.3 \%)^{*} \\
\text { Post-treatment transfusion: } \\
\text { OTSC }(0.68) \text { vs. Standard } \\
(0.04)^{*}\end{array}$ \\
\hline
\end{tabular}

SRH is stigmata of recent hemorrhage. Major SRH are active arterial bleeding (Forrest IA), non-bleeding visible vessel (FIIA), or adherent clot (FIIB). Lesser SRH are oozing bleeding (FIA) or flat spot (FIIC) with underlying arterial blood flow by DEP

strictures, stenoses or the compressed upper esophageal sphincter area in intubated patients; and challenge in positioning and deploying the device, especially with tangential positions of the lesion or SRH (Table 2). Greater than 120 degree tip angulation in each quadrant is an important requirement with the endoscope to be able to access, target, and successfully deploy OTSC onto focal lesions such as ulcers or DL with SRH. There also is a learning curve for unfamiliar endoscopists utilizing this accessory, especially with emergencies.

There are a number of techniques that the endoscopist can employ to optimize OTSC use, especially when treating fibrotic ulcers. First, it is essential to center the SRH in the ulcer base in the cap of the OTSC. This is best achieved using a diagnostic endoscope with at least 120 degrees of tip control in all four turning quadrants, as described above. Second, the endoscopist should push the tip of the OTSC cap firmly against the ulcer base and maintain constant firm pressure, with the SRH in the center of the cap, while the clip is deployed. We recommend that the endoscopist maintain the position of the SRH within the cap (with firm pressure) while an assistant turns the wheel to deploy the clip. Lastly, selection of the correct OTSC device is important. The 11-mm- and 12-mm-diameter OTSC kits are preferred in patients with an endotracheal tube, as it can be difficult to intubate the esophagus with larger diameter OTSC. We also recommend using the OTSC with the 3-mm cap, as the OTSC systems with a longer cap can be more challenging to maintain in position centered over the SRH. While standardization is important, these techniques are best taught at the bedside by experts.

Because of its ability to grasp larger amounts of tissue than through-the-scope hemoclips and also fibrotic tissue with significant compression force, we hypothesized that OTSC would be more effective at treating NVUGI hemorrhage than standard endoscopic hemostasis techniques. For NVUGIH, rates of persistent arterial blood flow and rebleeding were monitored by DEP in a recent report [35]. The rates of residual blood flow after standard visually guided endoscopic hemostasis of major SRH were significantly higher than OTSC-treated lesions ( $24 \%$ vs 5\%) and the rebleeding rates were also significantly higher $(26 \%$ vs. $5 \%$ ). As with DEP-guided hemostasis, successful obliteration of arterial blood flow with OTSC leads to definitive hemostasis of severe focal NVUGIH [10, 11, 35].

Prospective randomized reports on the use of OTSC are currently limited to two RCTs (Table 4). A recent study by the CURE Hemostasis group is the only prospective, randomized study describing the use of OTSC in the first line setting for treatment of severe upper GI hemorrhage [36]. This two center trial randomized 53 patients with either peptic ulcer disease $(91 \%)$ or DL $(9 \%)$ to treatment with OTSC or standard therapy (MPEC and/or HC, \pm epinephrine pre-treatment of active bleeding or adherent clots) with subsequent management by physicians blinded to the endoscopic treatment. We reported a significantly lower rate of 30-day rebleeding in the OTSC arm when compared to the standard therapy arm $(28.6 \%$ vs. $4 \%$; $=0.017)$ with a NNT of 4 . All of the rebleeds occurred in patients with major stigmata of recent hemorrhage (active spurting or pulsatile arterial bleeding, NBVV, or adherent clot) and no patient with lesser stigmata (oozing or flat spot with positive arterial Doppler signal) rebled. Severe medical complications and post-treatment $\mathrm{RBC}$ transfusions were also significantly less frequent in the OTSC group when compared to the standard group [36].

The OTSC was also reported in an earlier trial ("STING") that randomized 66 patients with recurrent peptic ulcer bleeding to either OTSC or standard therapy with epinephrine injection and/or through-the-scope clips as retreatment of peptic ulcer bleeds (PUBs) [37]. There were major methodologic differences from the CURE RCT because crossover was the design and patient care physicians were not blinded to the endoscopic treatments. The authors reported 
Table 5 Prospective studies of TC-325 (hemospray) in non-variceal upper GI hemorrhage (NVUGIH)

\begin{tabular}{|c|c|c|c|c|c|}
\hline Author & Study design and size & Study population & Treatment & Immediate hemostasis & Rebleeding rates \\
\hline Pittayanon [54] & $\begin{array}{l}\text { Prospective Cohort } \\
(\mathrm{N}=10)\end{array}$ & Tumors & $\begin{array}{l}\mathrm{N}=10 \\
\text { Hemospray-10 } \\
\text { Historical Con- } \\
\text { trol-10 }\end{array}$ & - & $\begin{array}{l}\text { Hemospray: } 10 \% \\
\text { Historical Control: } 30 \%\end{array}$ \\
\hline Haddara [55] & $\begin{array}{l}\text { Prospective Observa- } \\
\text { tional } \\
(\mathrm{N}=202)\end{array}$ & $\begin{array}{l}\text { PUD }(31 \%) \\
\text { Tumors }(30 \%) \\
\text { Post-endoscopic } \\
\quad(17 \%)\end{array}$ & All Hemospray & Hemospray: $96.5 \%$ & $\begin{array}{l}\text { Overall: } 33.5 \% \\
\text { PUD: } 38 \% \\
\text { Tumors: } 25 \% \\
\text { Post-endoscopic: } 33.5 \%\end{array}$ \\
\hline Kwek [48] & $\begin{array}{l}\text { RCT } \\
(\mathrm{N}=19)\end{array}$ & PUD & $\begin{array}{l}\mathrm{N}=19 \\
\text { Hemospray-9 } \\
\text { Conventional-10 }\end{array}$ & $\begin{array}{l}\text { Hemospray: } 90 \% \\
\text { Hemoclip: } 100 \%\end{array}$ & $\begin{array}{l}\text { Hemospray: } 33 \% \\
\text { Hemoclip: } 10 \%\end{array}$ \\
\hline Baracat [42] & $\begin{array}{l}\mathrm{RCT} \\
(\mathrm{N}=39)\end{array}$ & $\begin{array}{l}\text { Active Bleeding } \\
\text { PUD (44\%) } \\
\text { "Other" }(16 \%) \\
\text { Malignancy }(13 \%) \\
\text { Mallory-Weiss }(8 \%)\end{array}$ & $\begin{array}{l}\mathrm{N}=39 \\
\text { Hemospray-19 } \\
\text { Hemoclip-20 }\end{array}$ & $\begin{array}{l}\text { Hemospray: } 95 \% \\
\text { Hemoclip: } 90 \%\end{array}$ & $\begin{array}{l}\text { Hemospray: } 27.8 \% \\
\text { Hemoclip:. } 15.8 \%\end{array}$ \\
\hline Chen [43] & $\begin{array}{l}\mathrm{RCT} \\
(\mathrm{N}=20)\end{array}$ & Tumors & $\begin{array}{l}\mathrm{N}=20 \\
\text { Hemospray-10 } \\
\text { Conventional-10* }\end{array}$ & $\begin{array}{l}\text { Hemospray: } 90 \% \\
\text { Hemoclip: } 40 \%\end{array}$ & $\begin{array}{l}\text { Hemospray: } 20 \% \\
\text { Hemoclip: } 60 \%\end{array}$ \\
\hline Alzoubaidi [56] & $\begin{array}{l}\text { Prospective Observa- } \\
\text { tional } \\
(\mathrm{N}=314)\end{array}$ & $\begin{array}{l}\text { PUD }(53 \%) \\
\text { Tumors }(16 \%) \\
\text { Post-endoscopic } \\
(16 \%)\end{array}$ & All hemospray & Hemospray: $89.5 \%$ & $\begin{array}{l}\text { Overall: } 10.3 \% \\
\text { Monotherapy: } 7.3 \% \\
\text { Combination: } 9.6 \%\end{array}$ \\
\hline Hussein [50] & $\begin{array}{l}\text { Prospective Observa- } \\
\text { tional } \\
(\mathrm{N}=202)\end{array}$ & PUD & All Hemospray & Hemospray: $88 \%$ & Overall: $17 \%$ \\
\hline Lau [41] & $\begin{array}{l}\mathrm{RCT} \\
(\mathrm{N}=224)\end{array}$ & $\begin{array}{l}\text { PUD (58\%) } \\
\text { Tumors (14.3\%) }\end{array}$ & $\begin{array}{l}\text { Hemospray-111 } \\
\text { Standard-113 }\end{array}$ & $\begin{array}{l}\text { Hemospray: } 2.7 \% \\
\text { Standard: } 9.7 \%\end{array}$ & $\begin{array}{l}\text { Hemospray: } 8.1 \% \\
\text { Standard: } 8.8 \%\end{array}$ \\
\hline
\end{tabular}

a composite primary outcome of "further bleeding," which included persistent bleeding despite treatment or rebleeding within 7 days. Further bleeding occurred in $57.6 \%$ of patients in the standard therapy group compared to $15.2 \%$ in the OTSC group $(\mathrm{p}=0.001)$. This was driven by rates of persistent bleeding despite initial re-treatment (42.4\% vs. $6.0 \%$; $\mathrm{p}=0.001)$ more so than 7 -day rebleeding $(16.1 \%$ vs $9.1 \%$; $\mathrm{p}=0.468$ ). A cost analysis based on the STING study results concluded that OTSC was cost effective in recurrent peptic ulcer bleeding, despite the increased cost of these clips [38].

\section{TC-325}

TC-325 (Hemospray, Cook Medical, Winston-Salem, North Carolina, USA) is a biologically inert powder that creates a mechanical barrier over bleeding sites when it comes in contact with aqueous solution. Its clinical GI use was first reported in a 2011 case series of 20 patients with peptic ulcer bleeding and it was approved by the US FDA for endoscopic hemostasis in 2018 [39]. Several international consensus statements support the use of TC-325 as temporizing therapy when experienced endoscopists are not available or other endoscopic modalities that are applied do not control active bleeding $[6,9]$.

The advantages of the TC-325 treatment are that it can be easily sprayed from a distance onto bleeding areas to slow or stop active bleeding.(Fig. 4) It does not require the level of expertise that is needed to identify, prepare, and effectively treat focal bleeding for definitive hemostasis with standard visually guided techniques of bleeding sites. TC-325 can also be used to treat diffuse mucosal or neoplasia bleeding. The major limitations of TC-325 as a topical agent are 1) that is sloughs off after a short time (usually $<24 \mathrm{~h}$ ), 2) it does not prevent rebleeding nor result in definitive hemostasis of focal lesions with NVUGIH because arterial blood flow underneath SRH is not obliterated, 3) additional endoscopic treatments to prevent rebleeding by obliterating arterial blood flow are required to achieve permanent hemostasis and 4) each treatment is expensive (\$2500 USD) (Table 2).

Several technical tips are important to remember when utilizing TC-325. First, it is important to take proactive measures to avoid catheter occlusion. This includes flushing the accessory channel with air prior to passing the catheter $\&$ avoiding direct contact between the catheter tip and pooled blood, mucosa, and the actively bleeding lesion. The endoscopist should avoid aspirating blood while the catheter 
Table 6 Overall rebleeding rates in PUBs from prospective trials

\begin{tabular}{lll}
\hline Hemostasis modality & Major stigmata (Forrest 1A, & $\begin{array}{l}\text { Lesser stigmata (Forrest 1B, } \\
\text { 2C)^ }(\%)\end{array}$ \\
\hline Doppler endoscopic probe (DEP) & 15.4 & 1.1 \\
Over-the-scope-clip (OTSC) & 9.4 & 11.5 \\
TC-325 (Hemospray) & 23.6 & 17.1 \\
\hline
\end{tabular}

*Major SRH are Forrest 1A (active arterial bleeding), Forrest 2A (non-bleeding visible vessel), Forrest 2B (adherent clot)

${ }^{\wedge}$ Lesser SRG are Forrest 1B (oozing bleeding) or Forrest 2C (flat spot with underlying arterial blood flow by DEP)

is in the accessory channel because this can lead to occlusion. Second, the endoscopist should maintain the catheter tip at least 1-2 cm away from the SRH in order to allow adequate visualization of the lesion without blood touching the device. Finally, the endoscopist should "paint" the actively bleeding lesion with several layers of TC-325. Multiple applications can facilitate hemostasis if the first layer of powder is unsuccessful [40].

Prospective data regarding the use of TC-325 in NVUGIH are limited at this time to four prospective randomized trials and observational studies (Table 5). Only published as an abstract, the largest RCT to date included 224 patients with active non-variceal bleeding that were randomly assigned to TC-325 or standard treatment [41]. The most prevalent etiologies of bleeding were peptic ulcer disease (58\%) and upper GI tumors (14.3\%). Oozing bleeding (Forrest 1B) was much more prevalent than active arterial bleeding (Forrest 1A). In intention-to-treat analysis, the authors reported 30-day rebleeding-free probabilities of $89.8 \%$ in the TC-325 group and $81.1 \%$ in the standard treatment group. Patients in the standard treatment group were significantly more likely to fail initial attempts to control active bleeding (OR $3.88,10.5-14.3)$. There were no significant differences in recurrent bleeding, death, or need for further interventions (endoscopic and/or angiographic). Among patients with bleeding ulcers $(\mathrm{N}=130)$, rebleeding occurred in $12.5 \%$ in the TC-325 group and $15.4 \%$ in the standard treatment group $(\mathrm{p}=0.612)$. The authors concluded that TC-325 was not inferior to standard endoscopic control of active bleeding from various non-variceal UGI lesions.

Several smaller randomized studies also compared TC-325 to standard endoscopic treatments. Bacarat et. al randomized 39 patients with active bleeding ( $84 \%$ oozing, $16 \%$ spurting) to first line treatment with TC-325 or standard hemoclips [42]. Peptic ulcer disease was the cause of bleeding in $44 \%$ of patients and other lesions included malignancy (13\%), post-sphincterotomy bleeding (10\%), Mallory-Weiss tear (8\%) and Dieulafoy's lesion (5\%). There was no difference between the TC-325 and hemoclip group in terms of primary hemostasis ( $94.9 \%$ vs $90 \% ; \mathrm{p}=0.487)$ and there was a nonsignificant trend toward increased rebleeding in the TC-325 group ( $27.9 \%$ vs. $15.8 \%$; $=0.572)$ at 1 week. There were no differences between the groups in rates of surgery, death, RBC transfusion or length of stay. Of the four patients with active bleeding from gastric tumors, none experienced rebleeding.

Another RCT examined the role of TC-325 in the management of tumor bleeding. The authors randomized 20 patients with acute bleeding from malignant tumors to either TC-325 or standard of care (thermal and/or injection therapies) [43]. Seventeen patients had bleeding in the upper GI tract. Immediate hemostasis was achieved in $90 \%$
Fig. 2 Over the scope clip (OTSC) distal attachment (a) and clip type $3 \mathrm{a}(\mathbf{b})$
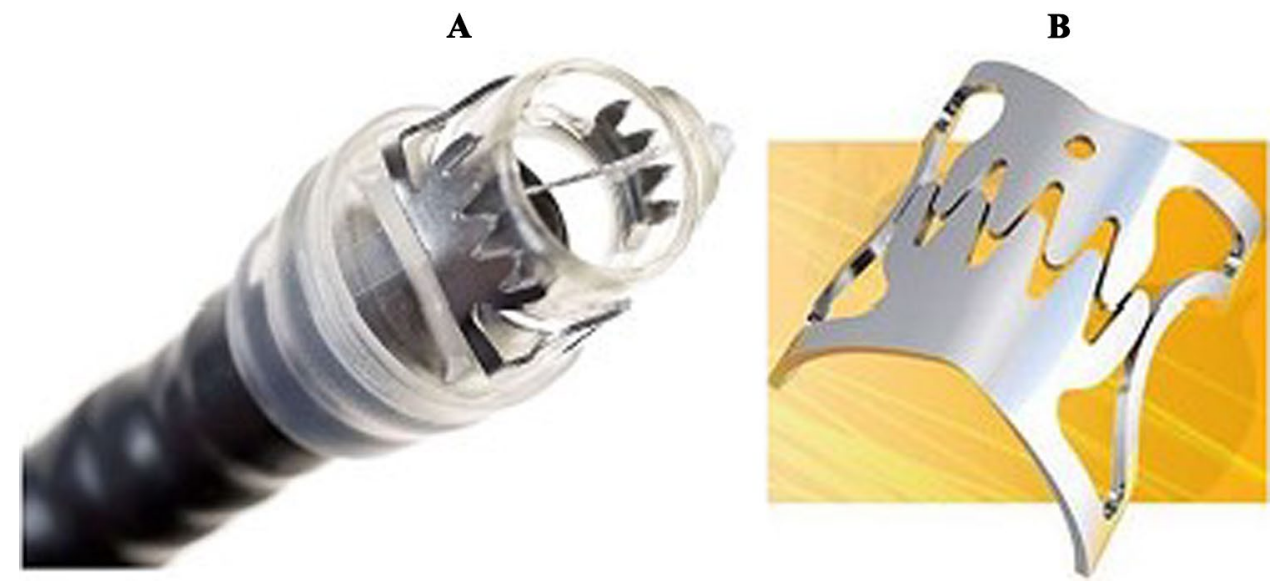
A

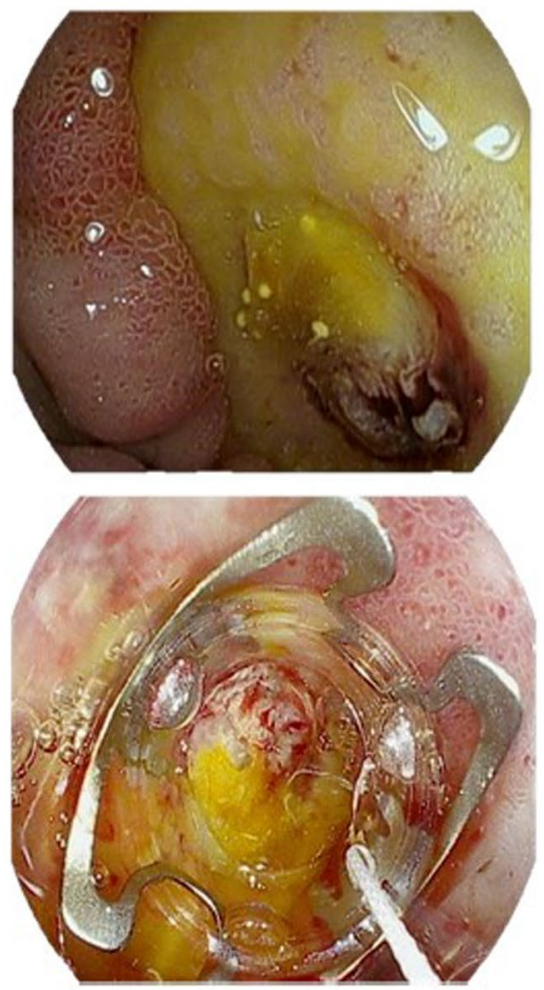

D
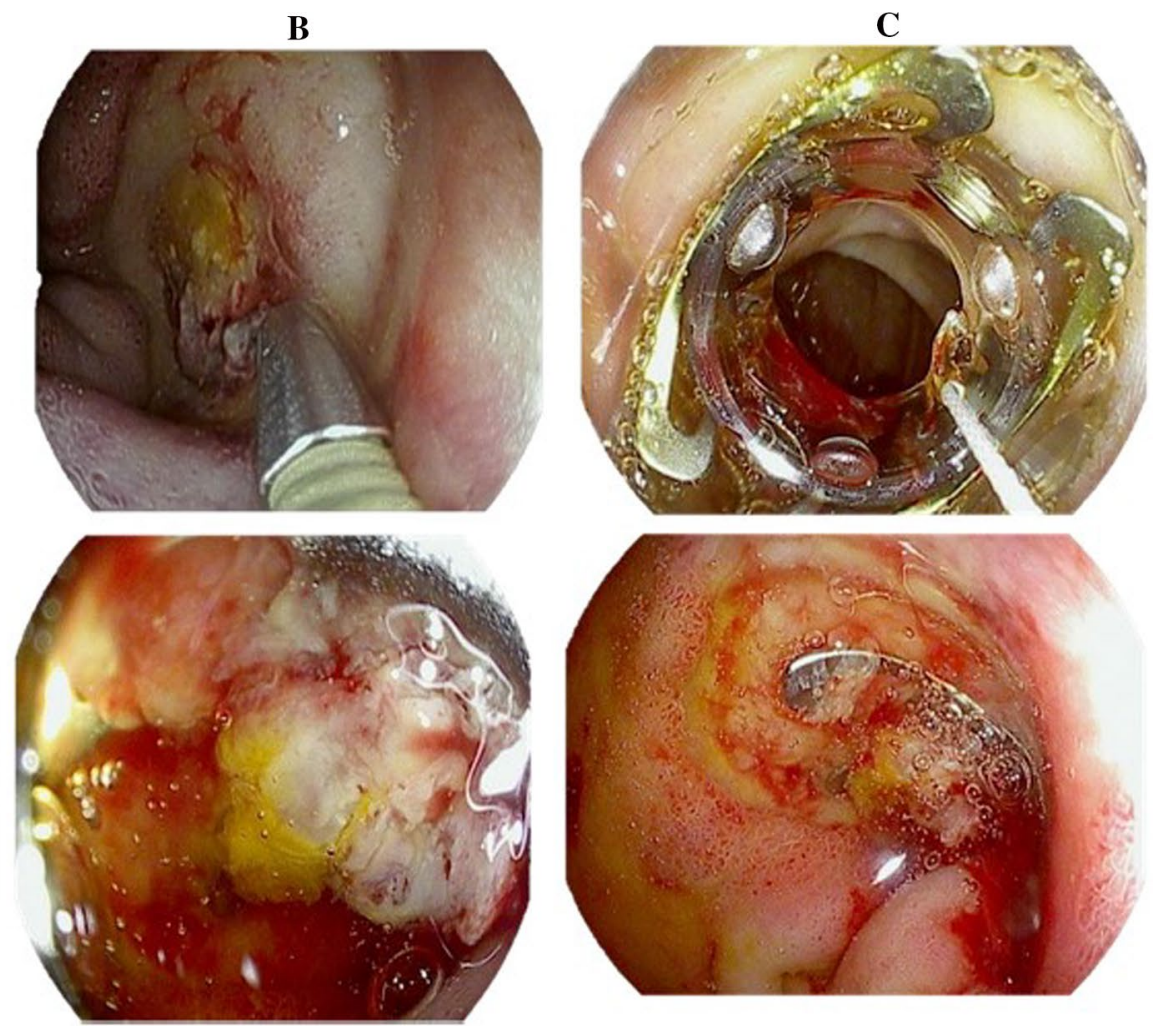

E

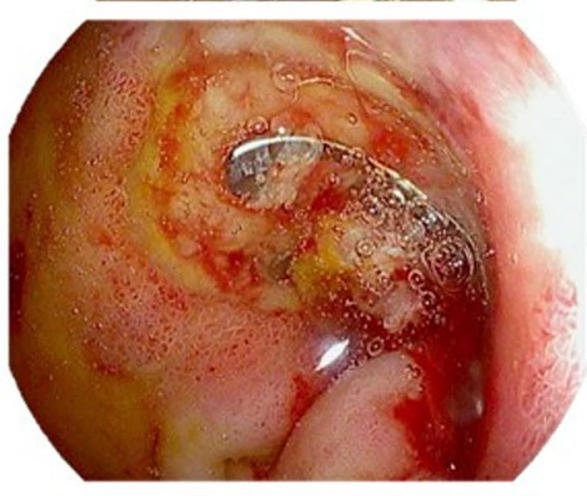

F

Fig. 3 Large duodenal bulb ulcer with visible vessel (Forrest 2A) (a) treated with epinephrine 1:10,000 injection (b). Passage of OTSC through pyloric channel (c) with application to ulcer bed (d) and deployment on stigmata (e) with subsequent hemostasis (f)

of patients treated with TC-325 and $40 \%$ in the standard care $\operatorname{arm}(\mathrm{p}=0.057)$. Rebleeding at 30 days occurred in $20 \%$ and $60 \%$ in the TC-325 and standard care arms, respectively $(\mathrm{p}=\mathrm{NS})$. The results of this study were included in a recent meta-analysis ( $2 \mathrm{RCT}, 2$ prospective observational) which reported an overall tumor rebleeding rate of $21.9 \%$ [44]. This rate compares favorably to prior studies of other endoscopic modalities which found rates of immediate hemostasis as low as $40 \%$ and rebleeding in up to $30 \%[45,46]$. However, rebleeding of UGI and colon lesions with TC-325 as primary treatment remains high [47]. Such significant rebleeding requires definitive treatment with other endoscopic, angiographic, or surgical modalities.

A final prospective study used TC-325 in the treatment of high-risk peptic ulcers. The investigators randomized 20 patients with high-risk peptic ulcers (Forrest 1A, 2A, 2B) to standard treatment or TC-325 [48]. There was a nonsignificant trend towards increased rebleeding during second look endoscopy among those treated with TC-325 (33\% vs. $10 \% ; \mathrm{p}=0.582$ ).

Other case series reported rebleeding rates of $10-19 \%$ when TC-325 was used as monotherapy for peptic ulcer bleeding (PUB) [39, 49]. A recent registry analysis including more than 200 patients with actively bleeding ulcers reported initial hemostasis in $88 \%$ and rebleeding in $17 \%$ of patients [50]. At this time, the available data suggests that TC-325 is best used in cases of either active bleeding that cannot be controlled by the endoscopist using standard therapies or in diffuse tumor bleeding, which is not amenable to standard thermal or mechanical treatments. For patients with active arterial bleeding from PUBs, DLs or other focal NVUGI lesions, as opposed to oozing bleeding, TC-325 appears to be only a temporizing measure because it does not obliterate underlying arterial blood flow in focal lesions such as peptic ulcers or Dieulafoy's lesions [10, 11, 47]. Definitive hemostasis by experienced endoscopists is required to prevent rebleeding in such patients.

\section{Conclusion}

Severe non-variceal upper GI bleeding from focal lesions such as PUBs and DLs remains a common clinical problem. Rebleeding is common when major SRH are treated with standard, visually guided hemoclipping or thermal coagulation [10, 11, 15, 36]. Doppler endoscopic probe and over-the-scope clip are promising new techniques that can decrease rebleeding rates, especially in high-risk patients 
(Table 6). TC-325 appears to be useful as a temporizing measure for continued bleeding of NVUGIH when standard hemostasis fails or is not available by skilled endoscopists or for palliation of diffuse tumor bleeding until more definitive treatments can be administered. Residual arterial blood flow in focal NVUGIH after standard hemostasis or TC-325 is a major risk factor for recurrent bleeding. Additional randomized, controlled trials are warranted to better define the respective roles of these new endoscopic treatments in the management of severe bleeding and whether these are cost effective. Finally, didactic and hands-on training sessions are needed and highly recommended to teach trainees and clinicians when and how to utilize these new hemostasis techniques [36, 51].

\section{Summary}

- Doppler endoscopic ultrasound (DEP), over-the-scope clip (OTSC), and TC-325 are promising new techniques for managing non-variceal upper-GI hemorrhage.

- DEP is easy to use and assists in lesion risk stratification and targeted obliteration of SRH of focal NVUGI lesions with underlying arterial blood flow.

- OTSC is useful for treating large or fibrotic ulcers to reduce rebleeding when compared to standard therapy, but training of endoscopists is needed.

- TC-325 is useful for treating diffuse bleeding of tumors and achieving initial hemostasis of active bleeding when standard hemostasis fails. However, underlying arterial blood flow is not obliterated by this topical technique and rebleeding of NVUGIH is common.

- Additional randomized clinical trial data is needed to better understand the clinical role for these novel endoscopic therapies.

- Didactic instruction about the indications and limitations of these new techniques and hands-on training are also recommended for both GI trainees and GI clinicians prior to application in emergency EGDs.
Funding Dr. Jensen and the CURE GI Hemostasis Research Unit studies were funded by NIH: NIDDK P30DK04301 CURE:DDRC (Human Studies Core), VA Clinical Merit Review Grants (CLIN-013-07F and 5I01CX001403) and the ASGE Research Foundation.

\section{Compliance with Ethical Standards}

Conflict of interest The authors declare that they have no conflict of interest.

Open Access This article is licensed under a Creative Commons Attribution-NonCommercial 4.0 International License, which permits any non-commercial use, sharing, adaptation, distribution and reproduction in any medium or format, as long as you give appropriate credit to the original author(s) and the source, provide a link to the Creative Commons licence, and indicate if changes were made. The images or other third party material in this article are included in the article's Creative Commons licence, unless indicated otherwise in a credit line to the material. If material is not included in the article's Creative Commons licence and your intended use is not permitted by statutory regulation or exceeds the permitted use, you will need to obtain permission directly from the copyright holder. To view a copy of this licence, visit http://creativecommons.org/licenses/by-nc/4.0/.

\section{References}

1. Wuerth BA, Rockey DC. Changing epidemiology of upper gastrointestinal hemorrhage in the last decade: a nationwide analysis. Dig Dis Sci 2018;63:1286-1293.

2. Barkun AN, Bardou M, Kuipers EJ, Sung J, Hunt RH, Martel M et al. International consensus recommendations on the management of patients with nonvariceal upper gastrointestinal bleeding. Ann Intern Med 2010;152:101-113.

3. Laine L, Jensen DM. Management of patients with ulcer bleeding. Am J Gastroenterol 2012;107:345-360.

4. Gralnek IM, Dumonceau J-M, Kuipers EJ, Lanas A, Sanders DS, Kurien $\mathrm{M}$ et al. Diagnosis and management of nonvariceal upper gastrointestinal hemorrhage: European Society of Gastrointestinal Endoscopy (ESGE) Guideline. Endoscopy 2015;47:a1-46.

5. Camus M, Jensen DM, Kovacs TO, Jensen ME, Markovic D, Gornbein J. Independent risk factors of 30-day outcomes in 1264 patients with peptic ulcer bleeding in the USA: large ulcers do worse. Aliment Pharmacol Ther 2016;43:1080-1089.
Fig. 4 Diffuse oozing from portal hypertensive gastropathy (a) treated with TC-325 with subsequent hemostasis (b)
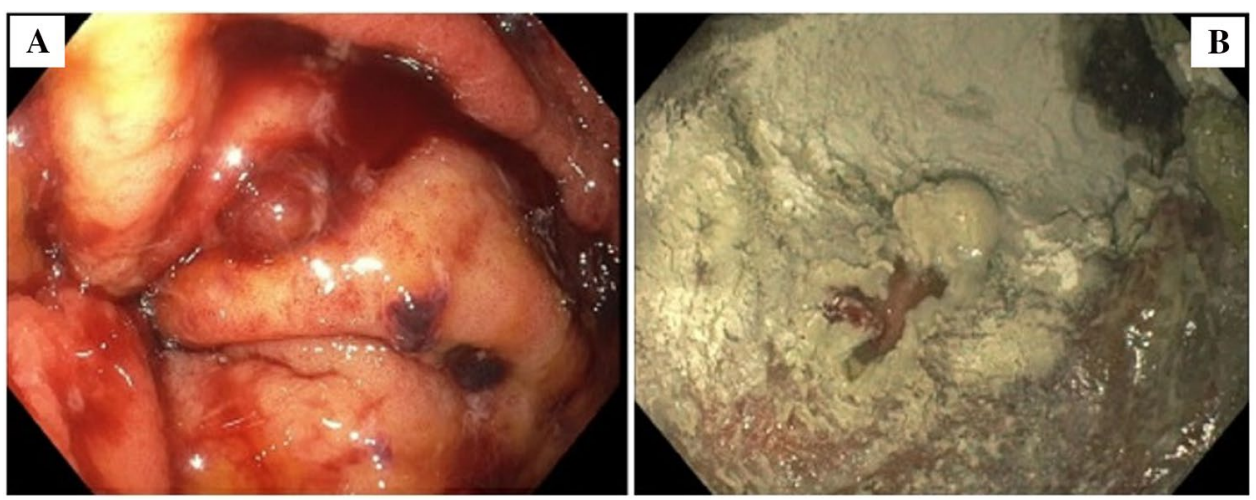
6. Sung JJ, Chiu PW, Chan FKL, Lau JY, Goh K-L, Ho LH et al. Asia-Pacific working group consensus on non-variceal upper gastrointestinal bleeding: an update 2018. Gut 2018;67:1757-1768.

7. Chiu PWY, Ng EKW, Cheung FKY, Chan FKL, Leung WK, Wu JCY et al. Predicting mortality in patients with bleeding peptic ulcers after therapeutic endoscopy. Clin Gastroenterol Hepatol 2009;7:311-316.

8. Marmo R, Koch M, Cipolletta L, Bianco MA, Grossi E, Rotondano $\mathrm{G}$ et al. Predicting mortality in patients with in-hospital nonvariceal upper GI bleeding: a prospective, multicenter database study. Gastrointest Endosc 2014;79:741-749.

9. Barkun AN, Almadi M, Kuipers EJ, Laine L, Sung J, Tse F et al. Management of nonvariceal upper gastrointestinal bleeding: guideline recommendations from the international consensus group. Ann Intern Med 2019;171:805-822.

10. Jensen DM, Kovacs TOG, Ohning GV, Ghassemi K, Machicado GA, Dulai GS et al. Doppler endoscopic probe monitoring of blood flow improves risk stratification and outcomes of patients with severe nonvariceal upper gastrointestinal hemorrhage. Gastroenterology 2017;152:1310-1318.

11. Jensen DM, Ohning GV, Kovacs TOG, Ghassemi KA, Jutabha $\mathrm{R}$, Dulai GS et al. Doppler endoscopic probe as a guide to risk stratification and definitive hemostasis of peptic ulcer bleeding. Gastrointest Endosc 2016;83:129-136.

12. Beckly DE, Casebow MP, Pettengell KE. The use of a Doppler ultrasound probe for localising arterial blood flow during upper gastrointestinal endoscopy. Endoscopy 1982;14:146-147.

13. Lau JY, Sung JJ, Chan AC, Lai GW, Lau JT, Ng EK et al. Stigmata of hemorrhage in bleeding peptic ulcers: an interobserver agreement study among international experts. Gastrointest Endosc 1997;46:33-36.

14. Wong RCK. Endoscopic Doppler US probe for acute peptic ulcer hemorrhage. Gastrointest Endosc 2004;60:804-812.

15. Nulsen B, Jensen DM, Kovacs TOG, Ghassemi KA, Kaneshiro M, Dulai DS et al. Outcomes in severe upper GI hemorrhage from Dieulafoy's Lesion with monitoring of arterial blood flow. Dig Dis Sci 2020. https://doi.org/10.1007/s10620-020-06679-4

16. Kohler B, Rieman JF. Does Doppler ultrasound improve theosis of acute ulcer bleeding? Hepatogastroenterology 1994;41:51-53.

17. Fullarton GM, Murray WR. Prediction of rebleeding in peptic ulcers by visual stigmata and endoscopic Doppler ultrasound criteria. Endoscopy 1990;22:68-71.

18. Kohler B, Maier M, Benz C, Riemann JF. Acute ulcer bleeding. A prospective randomized trial to compare Doppler and Forrest classifications in endoscopic diagnosis and therapy. Dig Dis Sci 1997;42:1370-1374.

19. van Leerdam ME, Rauws EAJ, Geraedts AAM, Tijssen JGP, Tytgat GNJ. The role of endoscopic Doppler US in patients with peptic ulcer bleeding. Gastrointest Endosc 2003;58:677-684.

20. Wong RC, Chak A, Kobayashi K, Isenberg GA, Cooper GS, CarrLocke DL et al. Role of Doppler US in acute peptic ulcer hemorrhage: can it predict failure of endoscopic therapy? Gastrointest Endosc 2000;52:315-321.

21. McCarthy TR, Sharma P, Jirapinyo P, Saltzman JR, Jensen DM, Thompson CC. Use of Doppler endoscopic probe for peptic ulcer disease associated bleeding: a systematic review and meta-analysis. Gastroenterology 2020;158:S-582.

22. Chen VK, Wong RCK. Endoscopic Doppler ultrasound versus endoscopic stigmata-directed management of acute peptic ulcer hemorrhage: a multimodel cost analysis. Dig Dis Sci 2007;52:149-160.

23. Yu JX, Russell WA, Soetinko RM, Jensen DM. Cost effectiveness of doppler endoscopic probe guided therapy of hemorrhage from peptic ulcers with flat pigmented spots. Gastrointest Endosc 2020;91:49.
24. McCarty RE, Jirapinyo P, James L, Saltzman JR, Jensen DM, Thompson CC. Use of doppler endoscopic probe is cost-effective for the management of peptic ulcer- associated hemorrhage. Gastrointest Endosc 2020;91:AB582-583.

25. Kirschniak A, Kratt T, Stüker D, Braun A, Schurr M-O, Königsrainer A. A new endoscopic over-the-scope clip system for treatment of lesions and bleeding in the GI tract: first clinical experiences. Gastrointest Endosc 2007;66:162-167.

26. Kirschniak A, Subotova N, Zieker D, Königsrainer A, Kratt T. The Over-The-Scope Clip (OTSC) for the treatment of gastrointestinal bleeding, perforations, and fistulas. Surg Endosc 2011;25:2901-2905.

27. Manta R, Mangiafico S, Zullo A, Bertani H, Caruso A, Grande $\mathrm{G}$ et al. First-line endoscopic treatment with over-the-scope clips in patients with either upper or lower gastrointestinal bleeding: a multicenter study. Endosc Int Open 2018;6:E1317-E1321.

28. Manno M, Mangiafico S, Caruso A, Barbera C, Bertani H, Mirante VG et al. First-line endoscopic treatment with OTSC in patients with high-risk non-variceal upper gastrointestinal bleeding: preliminary experience in 40 cases. Surg Endosc 2016;30:2026-2029.

29. Skinner M, Gutierrez JP, Neumann H, Wilcox CM, Burski C, Mönkemüller K. Over-the-scope clip placement is effective rescue therapy for severe acute upper gastrointestinal bleeding. Endosc Int Open 2014;2:E37-40.

30. Richter-Schrag H-J, Glatz T, Walker C, Fischer A, Thimme R. First-line endoscopic treatment with over-the-scope clips significantly improves the primary failure and rebleeding rates in highrisk gastrointestinal bleeding: a single-center experience with 100 cases. World J Gastroenterol 2016;22:9162-9171.

31. Wedi E, von Renteln D, Gonzalez S, Tkachenko O, Jung C, Orkut $\mathrm{S}$ et al. Use of the over-the-scope-clip (OTSC) in non-variceal upper gastrointestinal bleeding in patients with severe cardiovascular comorbidities: a retrospective study. Endosc Int Open 2017;5:E875-E882.

32. Lamberts R, Koch A, Binner C, Zachäus M, Knigge I, Bernhardt $\mathrm{M}$ et al. Use of over-the-scope clips (OTSC) for hemostasis in gastrointestinal bleeding in patients under antithrombotic therapy. Endosc Int Open 2017;5:E324-E330.

33. Brandler J, Baruah A, Zeb M, Mehfooz A, Pophali P, Wong Kee Song L et al. Efficacy of over-the-scope clips in management of high-risk gastrointestinal bleeding. Clin Gastroenterol Hepatol 2018;16:690-696.

34. Wedi E, Fischer A, Hochberger J, Jung C, Orkut S, Richter-Schrag HJ. Multicenter evaluation of first-line endoscopic treatment with the OTSC in acute non-variceal upper gastrointestinal bleeding and comparison with the Rockall cohort: the FLETRock study. Surg Endosc 2018;32:307-314.

35. Jensen DM, Kovacs TOG, Ghassemi KA, Kaneshiro M, Dulai G, Machicado GA. Why over-the-scope-clip is potentially more effective than standard endoscopic hemostasis as primary treatment of severe non-variceal upper gastrointestinal bleeding. Gastrointest Endosc 2019;89:72.

36. Jensen DM, Kovacs TOG, Ghassemi K. Randomized controlled trial (RCT) of over-the-scope clip as initial endoscopic treatment of severe non-variceal upper gastrointestinal bleeding. Clin Gastro Hepatol. 2020. https://doi.org/10.1017/j.cgh.2020.08.046.

37. Schmidt A, Gölder S, Goetz M, Meining A, Lau J, von Delius $S$ et al. Over-the-scope clips are more effective than standard endoscopic therapy for patients with recurrent bleeding of peptic ulcers. Gastroenterology 2018;155:674-686.e6.

38. Kuellmer A, Behn J, Meier B, Wannhoff A, Bettinger D, Thimme $\mathrm{R}$ et al. Over-the-scope clips are cost-effective in recurrent peptic ulcer bleeding. United Eur Gastroenterol J 2019;7:1226-1233.

39. Sung JJY, Luo D, Wu JCY, Ching JYL, Chan FKL, Lau JYW et al. Early clinical experience of the safety and effectiveness of 
Hemospray in achieving hemostasis in patients with acute peptic ulcer bleeding. Endoscopy 2011;43:291-295.

40. Barkun A. ASGE Tech Talks-gastrointestinal bleed management using hemospray endoscopic hemostat. Uploaded by ASGE Physician Education Videos, 16 Oct 2018. www.youtube.com/watch? $\mathrm{v}=\_q a O Z i J e Q p 0$.

41. Lau JY, Pittayanon R, Kwek K, Tang RS, Chan H, Rerknimitr R et al. An non-inferiority randomized controlled trial to compare hemostatic powder Tc325 and standard therapy in bleeding from nonvariceal upper gastrointestinal causes. Gastrointest Endosc 2020;91:14.

42. Baracat FI, de Moura DTH, Brunaldi VO, Tranquillini CV, Baracat R, Sakai P et al. Randomized controlled trial of hemostatic powder versus endoscopic clipping for non-variceal upper gastrointestinal bleeding. Surg Endosc 2020;34:317-324.

43. Chen Y-I, Wyse J, Lu Y, Martel M, Barkun AN. TC-325 hemostatic powder versus current standard of care in managing malignant GI bleeding: a pilot randomized clinical trial. Gastrointest Endosc 2020;91:321-328.

44. Chahal D, Tandon P, Jogendran M, Zhao B, Donnellan F. Hemospray for gastrointestinal bleeding: a meta-analysis. Gastrointest Endosc 2020;91:AB281.

45. Loftus EV, Alexander GL, Ahlquist DA, Balm RK. Endoscopic treatment of major bleeding from advanced gastroduodenal malignant lesions. Mayo Clin Proc 1994;69:736-740.

46. Giday S, Van Alstine W, Van Vleet J, Ducharme R, Brandner E, Florea $\mathrm{M}$ et al. Safety analysis of a hemostatic powder in a porcine model of acute severe gastric bleeding. Dig Dis Sci 2013;58:3422-3428.

47. Chalal D, Lee JGH, Ali-Mohamad N, Donnellan F. High rate of rebleeding after application of hemospray for upper and lower gastrointestinal bleeds. Dig Liver Dis 2020;52:768-772.

48. Kwek BEA, Ang TL, Ong PLJ, Tan YLJ, Ang SWD, Law NM et al. TC-325 versus the conventional combined technique for endoscopic treatment of peptic ulcers with high-risk bleeding stigmata: a randomized pilot study. J Dig Dis 2017;18:323-329.

\section{Authors and Affiliations}

\section{B. Nulsen ${ }^{1,2,3,5}$. D. M. Jensen ${ }^{1,2,3,4}$}

1 CURE Digestive Diseases Core Research Center and CURE GI Hemostasis Research Unit, Los Angeles, CA, USA

2 David Geffen School of Medicine, Los Angeles, CA, USA

3 Vatche and Tamar Manoukian Division of Digestive Diseases and Department of Medicine, Los Angeles, CA, USA
49. Smith LA, Stanley AJ, Bergman JJ, Kiesslich R, Hoffman A, Tjwa ET et al. Hemospray application in nonvariceal upper gastrointestinal bleeding: results of the Survey to Evaluate the Application of Hemospray in the Luminal Tract. J Clin Gastroenterol 2014;48:e89-92.

50. Hussein M, Alzoubaidi D, Fraile-López M, Weaver M, OrtizFernández-Sordo' J, Bassett $\mathrm{P}$ et al. Hemostatic spray powder TC-325 in the primary endoscopic treatment of peptic ulcer related bleeding: multicentre international registry. Endoscopy 2021;53(1):36-43. https://doi.org/10.1055/a-1186-5360.

51. Dunkin BJ, Matthes K, Jensen DM. GI Hemostasis. In: Cohen J, ed. Oxford: Blackwell Publishing Ltd.; 2011; 170-187.

52. Jaspersen D, Körner T, Wzatek J, Schorr W, Gaster CB, Hammar $\mathrm{CH}$. Endoscopic Doppler sonography in gastroduodenal ulcer bleeding. Clin Investig 1992;70:705.

53. Jakobs R, Zoepf T, Schilling D, Siegel EG, Riemann JF. Endoscopic Doppler ultrasound after injection therapy for peptic ulcer hemorrhage. Hepatogastroenterology 2004;51:1206-1209.

54. Pittayanon R, Prueksapanich P, Rerknimitr R. The efficacy of Hemospray in patients with upper gastrointestinal bleeding from tumor. Endosc Int Open 2016;4:E933-E936.

55. Haddara S, Jacques J, Lecleire S, Branche J, Leblanc S, Le Baleur $\mathrm{Y}$ et al. A novel hemostatic powder for upper gastrointestinal bleeding: a multicenter study (the "GRAPHE" registry). Endoscopy 2016;48:1084-1095.

56. Alzoubaidi D, Hussein M, Rusu R, Napier D, Dixon S, Rey JW et al. Outcomes from an international multicenter registry of patients with acute gastrointestinal bleeding undergoing endoscopic treatment with Hemospray. Dig Endosc 2020;32(1):96105. https://doi.org/10.1111/den.13502.

Publisher's Note Springer Nature remains neutral with regard to jurisdictional claims in published maps and institutional affiliations.
4 Department of Medicine and GI Division, West Los Angeles Veterans Administration Medical Center, Los Angeles, CA, USA

5 UCLA Santa Monica Digestive Diseases, 1223 16th Street, Suite 3011, Santa Monica, CA 90404, USA 